\title{
C4 and plasma protein in hypertension during pregnancy with and without proteinuria
}

\section{G J Hofmeyr, T Wilkins, C W G Redman}

Nuffield Department of

Obstetrics and

Gynaecology, John

Radcliffe Hospital,

Headington, Oxford OX3 9DU

G J Hofmeyr, MRCOG, visiting professor

T Wilkins, senior medical laboratory scientific officer

C W G Redman, FRCP,

medicine

Correspondence to:

Professor G J Hofmeyr,

Department of Obstetrics and Gynaecology,

Coronation Hospital and

University of the

Witwatersrand, Parktown

2193, Johannesburg, South Africa.

$B M \mathcal{F} 1991 ; 302: 218$ clinical reader in obstetric

There is disagreement about whether an immune complex disorder contributes to the pathogenesis of pre-eclampsia. ${ }^{1}$ Serum concentrations of $\mathrm{C} 4$ are increased during normal pregnancy ${ }^{2}$ and have been reported to be increased, ${ }^{4}$ unchanged, ${ }^{25}$ and decreased ${ }^{3}$ in pre-eclampsia. We studied circulating $\mathrm{C} 4$ concentrations in women with hypertension during pregnancy with and without proteinuria in relation to plasma protein concentrations and urinary excretion of $\mathrm{C} 4$.

\section{Subjects, methods, and results}

We studied 59 women attending our hospital. Venous blood was taken before and five days after delivery from 10 women with proteinuric pre-eclampsia (maximum antenatal blood pressure at least $170 \mathrm{~mm} \mathrm{Hg}$ systolic or $110 \mathrm{~mm} \mathrm{Hg}$ diastolic settling to normal after delivery and new proteinuria of at least $500 \mathrm{mg} / 24 \mathrm{~h}$ ), 10 with non-proteinuric hypertension during pregnancy (at least $140 \mathrm{~mm} \mathrm{Hg}$ systolic and $90 \mathrm{~mm} \mathrm{Hg}$ diastolic), and only before delivery from 20 healthy controls matched for age, parity, and length of gestation. Serum C4 concentrations were measured by single radial immunodiffusion using Nor-partigen plates (Behring, Hounslow).

In the women with proteinuric hypertension antenatal $\mathrm{C} 4$, total protein, and albumin concentrations were significantly less than those of their matched controls (table). The concentrations in women with non-proteinuric hypertension were slightly lower than but not significantly different from those of the controls. At five days after delivery there were significant increases in $\mathrm{C} 4$ but not total protein or albumin concentrations in both hypertensive groups. The increase in $\mathrm{C} 4$ after delivery persisted after six weeks in a further group of 12 women with proteinuric preeclampsia (data not shown).

Median (range) values of serum C4, total protein, and albumin in proteinuric and non-proteinuric hypertensive women and controls before and five days after delivery. Comparisons are by Wilcoxon's matched pairs signed ranking test

\begin{tabular}{|c|c|c|c|c|c|}
\hline & $\begin{array}{l}\text { Women with } \\
\text { proteinuria }\end{array}$ & Controls & $\begin{array}{l}\text { Women without } \\
\text { proteinuria }\end{array}$ & Controls & $\begin{array}{c}\text { p Value for } \\
\text { women with } \\
\text { proteinuria } v \\
\text { non-proteinuria }\end{array}$ \\
\hline \multicolumn{6}{|c|}{ Before delivery } \\
\hline No & 10 & 10 & 10 & 10 & \\
\hline \multirow[t]{3}{*}{$\mathrm{C} 4(\mathrm{~g} / \mathrm{l})$} & $0 \cdot 27$ & $\begin{array}{c}0.39 \\
0.9-51\end{array}$ & 0.35 & 0.41 & \\
\hline & $(0 \cdot 16-0 \cdot 38)$ & $(0 \cdot 29-0.51)$ & $(0 \cdot 16-0 \cdot 44)$ & $(0 \cdot 23-0 \cdot 51)$ & \\
\hline & \multicolumn{2}{|c|}{$<0.002$} & & & \multirow[t]{2}{*}{$<0.07$} \\
\hline \multirow[t]{2}{*}{ Total protein $(\mathrm{g} / \mathrm{l})$} & $\begin{array}{c}58 \\
(50-68)\end{array}$ & $\begin{array}{c}67 \\
(58-74)\end{array}$ & $\begin{array}{c}65 \\
(61-81)\end{array}$ & $\begin{array}{c}68 \\
(65-74)\end{array}$ & \\
\hline & \multicolumn{2}{|c|}{$<0 \cdot 02$} & & & \multirow[t]{2}{*}{$<0.001$} \\
\hline \multirow[t]{3}{*}{ Albumin $(\mathrm{g} / \mathrm{l})$} & $\begin{array}{c}22 \\
(16-26)\end{array}$ & $\begin{array}{c}32 \\
(20-40)\end{array}$ & $\begin{array}{c}28 \\
(25-34)\end{array}$ & $\begin{array}{c}31 \\
(26-39)\end{array}$ & \\
\hline & \multicolumn{2}{|c|}{$<0.02$} & \multirow{2}{*}{\multicolumn{2}{|c|}{ NS }} & $<0.02$ \\
\hline & \multicolumn{2}{|c|}{ After delivery } & & & \\
\hline & 10 & & $9^{\star \star}$ & & \\
\hline \multirow{2}{*}{$\mathrm{C} 4(\mathrm{~g} / \mathrm{l})^{\star}$} & 0.43 & & 0.42 & & \\
\hline & $(0 \cdot 19-0 \cdot 82)$ & & $(0 \cdot 19-0 \cdot 56)$ & & \\
\hline Total protein $(\mathrm{g} / \mathrm{l})$ & $\begin{array}{c}61 \\
(54-72)\end{array}$ & & $\begin{array}{c}69 \\
(64-76)\end{array}$ & & \\
\hline Albumin $(g / l)$ & 23 & & 30 & & \\
\hline & $(19-30)$ & & $(23-32)$ & & \\
\hline
\end{tabular}

$\star$ Proteinuric women: before $v$ after delivery $<0 \cdot 01$; non-proteinuric women before $v$ after delivery $<0 \cdot 01$. $\star \star$ One sample lost.
To determine whether substantial amounts of $\mathrm{C} 4$ might be lost in the urine seven women with proteinuric pre-eclampsia were studied before birth and five days after birth. Urine samples collected into EDTA and frozen immediately were concentrated to $0 \cdot 009-0 \cdot 014$ of the original volume using 10000 daltons exclusion filters (Amicon, Stonehouse) and C4 measured with a nephelometer (Baker-Encore) in the department of immunology. Urinary $\mathrm{C} 4$ was detected at the lower limit of the assay $(0.0005 \mathrm{~g} / \mathrm{l}$ after correction for the concentration factor) in one postpartum sample, giving a urine to plasma ratio 0.04 times that of protein, and was undetectable in all other samples. In five samples the urine to plasma ratio of protein was sufficiently high for $\mathrm{C} 4$ to have been detectable if present in a urine to plasma ratio one tenth that of protein.

\section{Comment}

We have shown that reduced circulating $\mathrm{C} 4$ concentrations are a feature of proteinuric rather than non-proteinuric hypertension during pregnancy. Whether this represents a specific association of low $\mathrm{C} 4$ concentrations with proteinuria or merely reflects a more advanced pre-eclamptic process is not clear. There are several possible reasons for the reduced C4 concentrations in patients with proteinuric hypertension. There may be consumption of $\mathrm{C} 4$ as part of a specific immunological process, as in autoimmune disease (though the decreases are slight compared with those recorded in systemic lupus erythematosus); there may be a non-specific depression of protein synthesis or an increase in protein catabolism; or there may be increased urinary loss of $\mathrm{C} 4$. The last explanation is unlikely given our failure to detect appreciable amounts of $\mathrm{C} 4$ in the urine, though the possibility of breakdown of $\mathrm{C} 4$ in the urine cannot be excluded. The factors responsible are unlikely to be the same as those responsible for the low albumin concentrations as there was no correlation between $\mathrm{C} 4$ and albumin concentrations within the proteinuric hypertensive group $(r=-0 \cdot 20)$.

The decrease in circulating $\mathrm{C} 4$ concentrations may be relevant to the pathogensis of pre-eclampsia and of diagnostic value, but at present the mechanisms for the change remain unclear.

We thank Sister V Mannion and Dr P Arkwright for their help, Dr H M Chapel and Dr G P Spickett for their collaboration, and the Harold Katz Memorial and AndersonCapelli funds for grants $(\mathrm{GJH})$.

1 Redman CWG. Immunology of the placenta. Clin Obstet Gynecol 1986;13 469-99.

2 Massobrio M, Benedetto C, Bertini E, Tetta C, Camussi G. Immune complexes in pre-eclampsia and normal pregnancy. Am f Obstet Gynecol 1985;152 $578-83$.

3 Buyon JP, Cronstein BN, Morris M, Tanner M, Weissmann G. Serum complement values $(\mathrm{C} 3$ and $\mathrm{C} 4$ ) to differentiate between systemic lupus activity and pre-eclampsia. Am f Med 1986;81:194-200.

4 Rosic B, Sulovic V, Juznik N, Lazarevic B, Vidanovic M. The significance of complement and immunoglobulin determination in healthy pregnant women and patients with EPH gestosis. Clin Exp Obstet Gynecol 1988;15:157-60.

5 Berge LN Ostensen M, Revhaug A. Phagocytic cell activity in pre-eclampsia Acta Obstet Gynecol Scand 1988;67:499-504.

(Accepted 12 October 1990

\section{Correction}

Effect of thiazide on rates of bone mineral loss: a longitudinal study

In the table of this article by Dr Richard Wasnich and colleagues ( 8 December $1990, p$ 1304) the p value for the distal radius should have read 0.3 rather than 0.03 . This error does not affect the main conclusion that users of thiazide have significantly slower bone loss rates than controls. 